\title{
PERBEDAAN KADAR HEMOGLOBIN PADA IBU HAMIL ANTARA PREEKLAMPSIA RINGAN DAN PREEKLAMPSIA BERAT
}

\author{
The Differences Hemoglobin level in women pregnancy with Mild \\ Preeclampsia and Severe Preeclampsia
}

\author{
Wuri Widi Astuti ${ }^{1}$, Ita Eko Suparni ${ }^{2}$ \\ ${ }^{1,2}$ Prodi D3 Kebidanan, STIKES Karya Husada Kediri \\ Korespondensi: wuriwidi@gmail.com
}

\begin{abstract}
ABSTRAK
Preeklampsia merupakan gangguan kesehatan yang terjadi khusus pada kehamilan yang dapat memengaruhi kesejahteraan ibu dan janin. Preeklampsia dapat berkembang menjadi kondisi yang mengancam jiwa dengan hemolisis umum, peningkatan enzim hati, jumlah trombosit yang rendah, dan peningkatan kadar hemoglobin $(\mathrm{Hb})$ bebas. Penelitian ini bertujuan untuk mengetahui perbedaan kadar hemoglobin pada ibu hamil dengan preeklampsia ringan dan preeklampsia berat di RSUD Kabupaten Kediri. Desain penelitian yang digunakan adalah deskriptif analitik dengan pendekatan cross sectional. Teknik sampling yang digunakan yaitu simple random sampling. Sampel pada penelitian ini adalah ibu hamil dengan pre eklampsia di RSUD Kabupaten Kediri periode JanuariAgustus 2018 sebanyak 30 responden yang memenuhi kriteria inklusi. Pengumpulan data dilakukan pada bulan September menggunakan data rekam medis. Analisa data menggunakan uji independent $t$ test didapatkan rata-rata kadar hemoglobin pada ibu dengan preeklampsia ringan adalah 12,600 g/dL, sedangkan preeklampsia berat mencapai $13,188 \mathrm{~g} / \mathrm{dL}$ dengan $\mathrm{p}>0,05 \quad(0,102)$. Tidak terdapat perbedaan bermakna kadar hemoglobin pada ibu hamil dengan preeklampsia ringan dan preeklampsia berat. Penting bagi bidan dan tenaga kesehatan untuk selalu melakukan pemantauan secara rutin terhadap kadar hemoglobin ibu hamil.
\end{abstract}

Kata kunci: kadar hemoglobin; preeklampsia; kehamilan

\begin{abstract}
Preeclampsia is a health disorder that occurs specifically in pregnancy that can affect the welfare of the mother and fetus. Preeclampsia can develop into a life-threatening condition with general hemolysis, an increase in liver enzymes, a low platelet count, and an increase in free hemoglobin $(\mathrm{Hb})$ levels. This study aims to determine the differences in hemoglobin levels in pregnant women with mild preeclampsia and severe preeclampsia in Kediri District Hospital. The research design used was descriptive analytic with cross sectional approach. The sampling technique used is simple random sampling. The sample in this study were pregnant women with pre-eclampsia in Kediri District Hospital from January to August 2018 as many as 30 respondents who met the inclusion criteria. Data collection was conducted in September using medical record data. Data analysis using independent $t$-test showed that the average hemoglobin level in women with mild preeclampsia was $12,600 \mathrm{~g} / \mathrm{dL}$, while severe preeclampsia reached $13,188 \mathrm{~g} / \mathrm{dL}$ with $\mathrm{p}>0.05(0.102)$. There were no significant differences in hemoglobin levels in pregnant women with mild preeclampsia and severe preeclampsia. It is important for midwives and health workers to always monitor regularly the hemoglobin levels of pregnant women.
\end{abstract}

Keywords: hemoglobin level; preeclampsia; pregnancy 


\section{PENDAHULUAN}

Preeklampsia merupakan gangguan kesehatan yang terjadi khusus pada kehamilan yang dapat memengaruhi kesejahteraan ibu dan janin serta terjadi komplikasi pada 3-5\% wanita hamil di seluruh dunia (Young, 2010). Penelitian Vata et al. (2015), sepuluh juta wanita di seluruh dunia mengalami preeklampsia setiap tahun. Dari kasus tersebut, 76.000 wanita hamil meninggal setiap tahun dari preeklampsia dan gangguan hipertensi terkait.

Di negara berkembang di mana akses ke pelayanan kesehatan terbatas, preeklampsia menjadi penyebab utama kematian ibu. Di Amerika, menunjukkan bahwa preeklampsia menyumbang sekitar $15,9 \%$ dari semua kematian ibu dan merupakan penyebab utama morbiditas dan mortalitas perinatal (Vata et.al,2015). Sekitar > 60.000 ibu diseluruh dunia meninggal setiap tahunnya (Young,2010).

Etiologi Preeklampsia belum diketahui namun Preeklampsia ditandai dengan terjadinya hipertensi dan proteinuria yang signifikan pada wanita hamil yang sebelumnya sehat dan muncul setelah minggu ke-20 kehamilan (Unamba, 2017). Meskipun etiologi preeklampsia belum diketahui, studi hemodinamik menunjukkan bahwa banyak temuan klinis yang dapat dijelaskan oleh gangguan vasokonstriksi umum dan fungsi sel endotel abnormal. Kejadian vasokonstriksi berkaitkan dengan peningkatan konsentrasi hemoglobin yang ditemukan pada ibu hamil dengan preeklampsia. Peningkatan konsentrasi hemoglobin dapat berasal dari hemoglobin bebas yang diturunkan dari perdarahan hemolitik plasenta pada kasus preeklampsia.

Hemoglobin bebas merupakan penyebab vasokonstriksi pada preeklampsia (Aghamohammadi, 2011). Preeklampsia dapat berkembang menjadi kondisi yang mengancam jiwa dengan hemolisis umum, peningkatan enzim hati, jumlah trombosit yang rendah, dan peningkatan kadar hemoglobin bebas ( $\mathrm{Hb})$, yang diklasifikasikan sebagai sindrom HELLP. Menurut klasifikasi dari organisasi kesehatan dunia (WHO), kadar hemoglobin wanita hamil adalah $11,0 \mathrm{~g} / \mathrm{dL}$ di trimester pertama dan ketiga. Sedangkan menurun atau kurang dari $10.5 \mathrm{~g} / \mathrm{dL}$ pada trimester kedua yang biasanya cenderung menyebabkan anemia pada trimester ini (Tabrizi, 2015).

Massa sel merah meningkat secara linier bersama dengan gestasi sekitar 25\% di atas level sebelum hamil. Karena itu, hemoglobin menurun dengan kehamilan mencapai titik nadir sekitar $15 \%$ pada kehamilan 30 minggu di bawah tingkat sebelum kehamilan. Tujuan dari pengenceran hemo fisiologis ini adalah untuk menciptakan sistem intravaskular lowviscositasis yang memungkinkan sirkulasi sel darah merah optimal dalam sirkulasi plasenta berkecepatan rendah dan sistem resistansi rendah untuk ventrikel kiri ibu agar tidak terjadi vasokonstriksi. Pada kejadian preeklampsia terjadi kegagalan untuk mencapai lingkungan viskositas darah rendah ini selama kehamilan sehingga berpengaruh terhadap homeostasis plasenta (Unamba, 2017).

Pada preeklampsia terjadi perubahan hematologi salah satunya adalah peningkatkan ekspresi gen heme $(\mathrm{Hb})$ yang terekam pada plasenta preeklampsia (Gathiram, 2016). Hasil Penelitian yang dilakukan oleh Wang (2016) menyebutkan bahwa kadar hemoglobin yang pada ibu hamil di trimester satu berperan dalam prediksi kejadian preeklampsia pada ibu hamil. Tiaranissa (2014) dalam penelitiannya menyebutkan bahwa kadar hemoglobin pada ibu hamil normal memiliki kadar yang lebih rendah dibandingkan pada ibu hamil dengan preeklampsia berat. Berdasarkan latar belakang tersebut peneliti bermaksud ingin mengetahui apakah tingkat dari preeklampsia yaitu preeklampsia ringan dan berat memiliki perbedaan terhadap kadar hemoglobin pada ibu hamil.

\section{TUJUAN PENELITIAN}

Penelitian ini bertujuan untuk mengetahui perbedaan kadar hemoglobin pada ibu hamil dengan preeklampsia ringan dan preeklampsia berat di RSUD Kabupaten Kediri. 


\section{METEDOLOGI PENELITIAN}

Desain

Desain penelitian yang digunakan adalah deskriptif analitik dengan pendekatan cross sectional.

\section{Populasi dan Sampel}

Populasi dalam penelitian ini adalah semua ibu hamil di RSUD Kabupaten Kediri. Teknik sampling yang digunakan yaitu simple random sampling. Sampel pada penelitian ini adalah ibu hamil dengan preeklampsia pada periode Januari-Agustus 2018 sebanyak 30 orang.

\section{Tempat dan Waktu Penelitian}

Penelitian ini dilakukan pada bulan September 2018 di RSUD Kabupaten
Kediri dengan sebelumnya dinyatakan laik etik oleh Komisi Etik STIKES Karya Husada Kediri.

\section{Instrumen dan Prosedur Pengukuran}

Pengumpulan data dilakukan dengan mengunakan rekam medis pasien yang terdokumentasi lengkap di RSUD Kabupaten Kediri baik untuk variabel preeklampsia maupun kadar hemoglobinnya.

\section{Analisa Data}

Analisa data menggunakan analisa univariat dan bivariate, dengan uji beda independent-t.

\section{HASIL PENELITIAN}

Hasil penelitian akan disajikan pada tabel sebagai berikut:

Tabel 1

Perbedaan Kadar Hemoglobin pada Ibu Hamil dengan Preeklampsia

\begin{tabular}{|c|c|c|c|c|c|c|}
\hline \multirow{3}{*}{ Kadar Hb } & PE & $\mathrm{N}$ & Mean & Std. Deviation & Std. Error Mean & Sig.(2-tailed) \\
\hline & PE Ringan & $13(43 \%)$ & 12,600 & 1,1045 & ,3063 & \multirow{2}{*}{0,102} \\
\hline & PE Berat & $17(57 \%)$ & 13,188 & ,8007 &, 1942 & \\
\hline
\end{tabular}

Pada tabel 1 menunjukkan sebagian besar ibu mengalami preeklampsia berat (57\%) dengan rata-rata kadar hemoglobin 13,188 gr/dL. Tidak terdapat perbedaan yang bermakna antara ibu dengan preeklampsia berat dengan preeklampsia ringan yang ditunjukkan oleh nilai $\mathrm{p}=0,102$.

\section{PEMBAHASAN}

Hasil dari analisa data menunjukkan bahwa rata-rata kadar hemoglobin pada ibu dengan preeklampsia ringan adalah 12,600 $\mathrm{g} / \mathrm{dL}$. Sedangkan pada ibu hamil dengan preeklampsia memiliki rata-rata kadar hemoglobin 13,188 g/dL. Hal ini menunjukkan bahwa rata-rata kadar $\mathrm{Hb}$ pada ibu hamil dengan preeklampsia berat lebih tinggi jika dibandingkan pada ibu hamil dengan preeklampsia ringan.

Kadar Hemoglobin pada ibu hamil normal adalah $11 \mathrm{~g} / \mathrm{dL}$ pada trimester pertama dan akan menurun pada trimester kedua atau pertengahan kehamilan (Tabrizi, 2015).Pada trimester kedua kadar Hemoglobin ibu mengalami penurunan hingga dibawa 10,5 g/dL. Hal ini merupakan suatu upaya sistem pertahanan tubuh untuk menciptakan sistem intravaskular lowviscositasis yang memungkinkan sirkulasi sel darah merah optimal dalam sirkulasi plasenta berkecepatan rendah dan sistem resistansi rendah untuk ventrikel kiri ibu agar tidak terjadi vasokonstriksi (Unamba, 2017).

Pada ibu hamil dengan preeklampsia kadar Hemoglobin pada trimester kedua ataupun pertengahan kehamilan cenderung lebih tinggi. Tinggi kadar hemoglobin pada preeklampsia salah satunya dipicu oleh disfungsi sel endotel. Cytotrophoblast yang gagal untuk merombak spiral arteri, menyebabkan hipoperfusi dan iskemia plasenta. Plasenta yang iskemik melepaskan faktor yang memprovokasi disfungsi endotel (Lambert, 2014). Disfungsi endotel mengakibatkan gangguan hematologis 
melalui kebocoran di antara celah celah sel endotel yang akan menyebabkan volume plasma mengalami penurunan di intravascular. Penurunan volume plasma ini menyebabkan hemokonsentrasi.

Pada ibu hamil dengan preeklampsia berat rata-rata kadar hemoglobin lebih tinggi. Preeklampsia berat memicu kerusakan dari sel endotel yang semakin tinggi sehingga hemokonsentrasi semakin parah. Hemokonsentrasi akan menimbulkan keadaan trombositopenia dan peningkatan produksi eritrosit, sehingga kadar hemoglobin juga ikut tinggi (Tiaranissa, 2014). Pada preeklampsia, hilangnya protein serum dan peningkatan permeabilitas kapiler kapiler menyebabkan penurunan volume intravaskuler dan peningkatan edema jaringan. Semua organ bisa terpengaruh, termasuk hati, otak,dan paru-paru. Penurunan volume darah dapat menyebabkan suatu peningkatan konsentrasi hemoglobin ibu. Mekanisme yang mendasari kontribusi dari kadar.

Hemoglobin pada preeklampsia terutama mungkin melibatkan tingginya viskositas darah. Hyperviskositas dapat secara langsung mengurangi aliran darah dalam mikrovaskulatur kekuatan kinetik rendah, seperti plasenta. Hal ini dapat menyebabkan berkurangnya perfusi dan oksigenasi jaringan plasenta, oleh karena itu memperburuk hipoksia jaringan plasenta sebagai akibat langsung dari sirkulasi plasenta berkecepatan rendah dan mengurangi suplai oksigen. Selain itu, Hemoglobin memiliki peran langsung dalam pengaturan oksida nitrat (NO) dan fungsi endotel. NO adalah vasodilator yang kuat dan dapat merelaksasi sel otot polos pembuluh darah. Hemoglobin bebas dapat mengikat dan meninaktifkan NO, sehingga menyebabkan vasokonstriksi dengan hipertensi konsekuen dan terjadinya iskemia plasenta. Selanjutnya, Hemoglobin teroksidasi dapat membuat deposit heme methemoglobin yang diturunkan pada endotelium vaskular, yang pada gilirannya secara langsung merusak endotelium atau mempromosikan pembentukan ateroma melalui efek oksidasi lipoprotein lowdensity (Wang, 2018).
Berdasarkan hasil analisis dari uji statistik menggunakan uji independent sampel t-tes didapatkan $\mathrm{p}>0,05(0,102)$ yang artinya bahwa tidak terdapat perbedaan yang bermakna antara kadar hemoglobin pada ibu dengan preeklampsia ringan maupun ibu yang mengalami preeklampsia berat. Meskipun secara ratarata kadar hemoglobin pada kasus preeklampsia berat lebih tinggi daripada preeklampsia ringan, namun perbedaan yang ditemukan tidak bersifat signifikan.

Hal ini dapat disebabkan oleh faktor-faktor yang berpengaruh terhadap kadar hemoglobin ibu hamil. Penelitian yang dilakukan oleh Ustun (2007) yang mengevaluasi kadar hemoglobin pada ibu hamil dengan preeklampsia ringan, sedang dan berat tidak menemukan adanya perbedaan yang bermakna pada kadar hemoglobin ibu. Dijelaskan dalam penelitiannya bahwa konsumsi tablet besi yang baik pada setiap ibu hamil berpengaruh pula pada kadar hemoglobin.

\section{KESIMPULAN}

Implikasi

Berdasarkan hasil dari analisis data yang dilakukan pada penelitian ini didapatkan bahwa tidak terdapat perbedaan yang bermakna/ signifikan antara kadar hemoglobin pada ibu hamil dengan preeklampsia ringan dengan ibu hamil dengan preeklampsia berat.

\section{Keterbatasan}

Dalam penelitian yang dilakukan ini belum mengkaji secara jauh tentang pola konsumsi ibu hamil serta faktor lain yang mempengaruhi kadar hemoglobin pada ibu. Sehingga perlu dilakukan penelitian lanjutan dengan jumlah responden yang lebih besar serta perlunya dilakukan pengukuran hemoglobin ulangan untuk memantau kadarnya.

\section{DAFTAR PUSTAKA}

Aghamohammadi, A.,M. Zafari and M. Tofighi. (2011). High maternal hemoglobin concentration in first trimester as risk factor for pregnancy induced hypertension. 
Wuri Widi Astuti, dkk: Perbedaan Kadar Hemoglobin Pada Ibu Hamil Antara Preeklampsia Ringan dan Preeklampsia Berat

Caspian J Intern Med. Vol 2(1): 194-197.

Gathiram, P and J. Moodley. (2016). preeclampsia: its pathogenesis and pathophysiolgy. Cardiovascular Journal Of Africa.Vol. 27(2).71-78

Lambert, G., J.F. BrIchant, G. HartsteIn, V.Bonhomme and P. Y. Dewandre.(2014). Preeclampsia : an update. Acta Anaesth. Belg. 65(4) :137-149

Tabrizi, M.F and S. Barjasteh. (2015). Maternal Hemoglobin Levels during Pregnancy and their Association with Birth Weight of Neonates. Iranian Journal of Pediatric Hematology Oncology.Vol.5(4): 211-217

Tiaranissa, A., S.C. Windu dan E. Sriwahyuni. (2014). Profil Kadar Hemoglobin pada Wanita PreEklampsia Berat Dibandingkan dengan Wanita Hamil Normal. Majalah Kesehatan FKUB. Vol.1 (3): 171-177

Unamba, B.C and N.O Rosemary. (2017). The Relationship between Haemoglobin

Concentration and Pregnancy Outcomes in Women with PreEclampsia in a Tertiary Hospital in South Southern, Nigeria. Journal of Gynecology and Women's Health. Vol.7 (2) :1-8.

Ustun, Y.E., K. Dogan, I. Türkçüoglu, Y. Üstün, M. M. Meydanli and A. Kafkasli. (2007). Evaluation of Hemoglobin and Platelet Levels in Mild, Moderate and Severe Preeclampsia. Perinatal Journal.Vol.15(3):93-98.

Vata, P.K., N.M.Chauhan., A. Nallathambi1 and F.Hussein. (2015). Assessment of prevalence of preeclampsia from Dilla region of Ethiopia. BioMed Central Research Note.Vol 8(816) : 1-6.

Wang, C., L. Lin, R. Su, W. Zhu, Y. Wei, J.Yan, H.Feng, B. Li, S. Li and H. Yang. (2018). Hemoglobin levels during the first trimester of pregnancy are associated with the risk of gestational diabetes mellitus, pre-eclampsia and preterm birth in Chinese women: a retrospective study. BMC Pregnancy and Childbirth. Vol 18 (263) : 2-11

Young,B.C., R.J Levine., and S.A. Karumanchi. (2010). Pathogenesis of Preeclampsia. Annu. Rev. Pathol. Mech. Dis. 5:173-92 